\title{
$\mathrm{C}$ 領域の胃癌の術式選択
}

\section{一特に stage III の切除術式の再検討一}

\begin{tabular}{lllllll}
\multicolumn{8}{c}{ 久留米大学第 1 外科教室 } \\
武田 仁良 & 掛川 & 暉夫 & 福嶋 & 博愛 & 北里 & 誠也 \\
小深田盛一 & 白井 & 文夫 & 橋本 & 謙 & 荒木 & 恒敏 \\
黒岩 達 & 村上 & 吉博 & 平井 & 裕 & &
\end{tabular}

\section{SURGICAL TREATMENTS FOR THE UPPER GASTRIC CANCER RETROSPECTIVE STUDIES OF THE STAGE III CANCER}

\section{Jinryo TAKEDA, Teruo KAKEGAWA, Hironaru FUKUSHIMA, Seiya KITASATO, SeiitiKOBUKATA, Fumio SHIRAI, Ken HASHIMOTO, Tunetoshi ARAKI, Tooru KUROIWA, Yoshihiro MURAKAMI and Yuu HIRAI}

The 1st department of Surgery, School of Medicine, Kurume University

\begin{abstract}
Cを中心とする胃癌を $\mathrm{C} ・ \mathrm{CE}$ 群と $\mathrm{CM} ・ \mathrm{CME}$ 群の 2 群に分け切除症例につき検討した. 切除率は非治㾤切除も含めて C・CE 群は175/181 96.7\%で CM・CME 群は65/115 56.5\%であった。 stage I, II の予後は良好であったが stage III では C・CE 群 $22.6 \%, \mathrm{CM} ・ \mathrm{CME}$ 群 $30.0 \%$ と良い結 果は得られず, 胃上部の癌の予後向上のためには症例も最も多い stage III の外科的治療成績向上が大 切で, そのためには胃全摘十膵脾合併切除を標準術式とし食道浸潤距離 $2 \mathrm{~cm}$ 以上は開胸の絶対的適応 で，特に CM・CME 群の低分化型の食道浸潤例ではより十分な食道岈除が必要で，また $\mathrm{P}$ 因子を配慮 したより広範な腹腔内臟器合併切除が必要であろう。
\end{abstract}

索引用語：C領域胃癌, 左開胸開腹, 龩脾合併切除, 上部胃癌の緃隔リンパ節転移, 下部食道切除と胃全摘

\section{はじめに}

胃癌取扱い規約の胃上部Cを中心とする癌手術のア プローチ，切除および再建術式は，諸家により，手術 の根治性と安全性などさまざまな観点から検討されて きたが，いまだ統一的な見解はないとい方る。

教室でもこの領域に占居する胃癌根治手術に対する アプローチとして, 開腹操作のミかに, 開胸又は胸骨 縦切開などを追加し, 下部食道切除を加えての噴門側 切除や全摘, また症例によっては非開胸食道拔去法に よる食道切除や腪脾合併切除を, その当時の適応に よって選択し行って来たが, stage III 以上の症例では 満足すべき成績を得たとはいい難い。

<1984年10月17日受理 >別刷請求先：武田 长良 T830 久留米市旭町 67 久留米大学医学部第 1 外科
そこで今回は教室の切除症例を臨床的, 病理学的に 再検討し, とりわけ, stage III 症例の術式選択につい て C・CE出よび $\mathrm{CM} \cdot \mathrm{CME}$ の両者の比較検討る加光, 反省を含めて若干の考察を行ってみた。

\section{対象および方法}

昭和46年から58年末までの13年間に教室に入院した Cを中心とする胃癌症例の296例を対象とした。 これ は, 同期間の胃癌患者粉数 1,411 例の $21 \%$ にある. 占居部位，進展型式を考慮し， $\mathrm{CE}(\mathrm{E}=\mathrm{C}$ む含む) ・ $\mathrm{C}$ の A 群181例と CM・CMEの B 群115例の 2 群に分 けて, 特に stage III 症例を中心に比較検討した.

検索項目は，1）年龄·性別頻度，2）切除率，3）占 居部位と進行程度，4）アプローチと切除術式，5）肉 眼型，6）組織型，7）リンパ節転移率，8）食道漫潤様 式，9）口側切除断端癌遺残，10）予後である. 
3）5６）7)は胃癌取扱い規約10版の分類に従い，3)以 下は切除症例で，7)は stage III についてのみ検討し た. 予後は累積生存率で算出し, 統計学的に有意差を 求めた.

\section{1）年齢 - 性別頻度}

\section{結果}

平均年龄は, A 群59.6歳, B 群58.5歳で差なく, 性 別は, A群は男性139例76.8\%, 女性42例23.2\%でB群 は男性77例 $67.0 \%$, 女性38例 $33.0 \%$ と B群に女性の頻 度が高かった。

2) 切除率

A群175/181 96.7\%，B群65/115 56.5\%で差がみら れた。

3）占居部位と進行程度

表 1 に示したが，早期癌はA群23例13.1\%，B群 3 例 $4.6 \%$ で少なく, 両群とも stage III, IV が約70\%を 占め, stage III はA 群 $45.7 \%, B$ 群 $36.9 \%$ と高率で あった。
4) アプローチと切除術式

$\mathrm{A}$ 群は, 開胸をたは胸骨縦切開が $36.0 \%$ に付加され， 切除術式は, 噴門側切除 (以下噴切) $40.0 \%$, 全摘 $48.0 \%$, 食道抜去法 $6.9 \%$ で, stage III では, 噴切27例, 全摘 40 例, 食道抜去法 8 例, 幽門側覀全摘 2 例であ。 た.脾摘または梳・脾合併切除は $58.9 \%$ に行われ, stage III では，噴切の14例，全摘の35例の計49例，63.6\%で あった。

B 群は，開腹のみによる切除が78.5\%で，全摘が $89.2 \%$ を占め, 合併切除は $78.5 \%$ あった. stage III は全例に全摘が行われ，21例87.5\%に合併切除が行わ れた（表 2).

5) 肉眼型

$\mathrm{A}$ 群の早期癌は, 陷山型が65.2\%, 進行癌は Borrmann 3 型が65.8\%を占め, B群では, 早期癌は全例 宿凹型で, 進行癌は A 群と同様 Borrmann 3 型が半数 以上を占めた（表 3 ).

6) 組織型

表 1 症 例

\section{A 群}

C. CE 181

男性 139 ( $76.8 \%)$

女性 $42(23.2 \%)$

平均年令 59.6

切除率 $175 / 181: 96.7 \%$

占居部位と stage

\begin{tabular}{c|rrrr|r} 
& 1 & 11 & II & IV & total \\
\hline $\mathrm{E}=\mathrm{C}$ & 3 & & 6 & 5 & 14 \\
$\mathrm{C}>\mathrm{E}$ & 4 & 6 & 42 & 26 & 78 \\
$\mathrm{C}$ & 27 & 14 & 32 & 10 & 83 \\
\hline tota 1 & 34 & 20 & 80 & 41 & 175
\end{tabular}

B 群

CM. CME 115

男性 $77(67.0 \%)$

女性 $38(33.0 \%)$

平均年命 58.5

切除案 $65 / 115: 56.5 \%$

表 2 アプローチと切除術式（）：合併切除

c. CE

\begin{tabular}{|c|c|c|c|}
\hline & 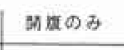 & 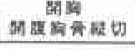 & H \\
\hline 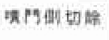 & $36(19)$ & $34(18)$ & $70(37)$ \\
\hline 全塔 & $55(42)$ & $29(24)$ & $84(66)$ \\
\hline 菲全揞 & 9 & & 9 \\
\hline 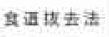 & 12 & & 12 \\
\hline it & $112(61)$ & $63(42)$ & $175(103)$ \\
\hline
\end{tabular}

CM . CME

\begin{tabular}{|c|c|c|c|}
\hline & 腢のみ & 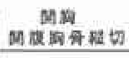 & it \\
\hline 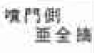 & 1 & $2(1)$ & $3(1)$ \\
\hline 全制 & $46(37)$ & $12(11)$ & $58(48)$ \\
\hline 踾全相 & $4(2)$ & & $4(2)$ \\
\hline if & $51(39)$ & $14(12)$ & $65(51)$ \\
\hline
\end{tabular}

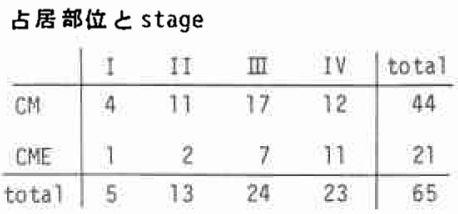


表 3 肉眼型

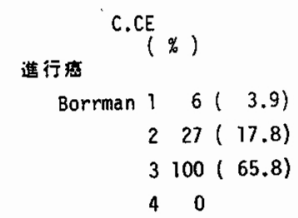

unclassified $19(12.5)$ $152(100.0)$

\section{早期现}

\begin{tabular}{|c|c|c|}
\hline I & $4(17.4)$ & \\
\hline II & $3(13.0)$ & $8(34.8)$ \\
\hline I Ia $+I_{b}$ & $1(4.4)$ & \\
\hline IIc & $10(43.5)$ & \\
\hline II $I_{c}+$ III & $5(21.7)$ & $65.2)$ \\
\hline
\end{tabular}

\section{表 4 組織型（\%)}

\begin{tabular}{lccc} 
& C & CE & \multicolumn{1}{c}{ total } \\
pap & $7(8.4)$ & $10(10.9)$ & $17(9.7)$ \\
tub ${ }_{1-2} 42(50.6)$ & $5(155.4)$ & $93(53.1)$ \\
por $22(26.5)$ & $23(25.0)$ & $45(25.7)$ \\
muc & $3(3.6)$ & & $3(1.7)$ \\
sig & $8(9.6)$ & $5(5.4)$ & $13(7.4)$ \\
sq & & 1 & 1 \\
cd & & 1 & 1 \\
ud & 1 & 1 & 2 \\
\hline & $83(100)$ & $92(100)$ & $175(100)$
\end{tabular}

\begin{tabular}{lccc} 
& CM & CME & total \\
pap & $4(9.1)$ & $2(9.5)$ & $6(9.2)$ \\
tub $_{1-2}(8(40.9)$ & $8(38.1)$ & $26(40.0)$ \\
por & $(8(40.9)$ & $7(33.3)$ & $25(38.5)$ \\
muc $\quad 1(2.3)$ & $2(9.5)$ & $3(4.6)$ \\
sig & $3(6.8)$ & $2(9.5)$ & $5(7.7)$ \\
\hline & $44(100)$ & $21(100)$ & $65(100)$
\end{tabular}

图1 リンパ節転移率
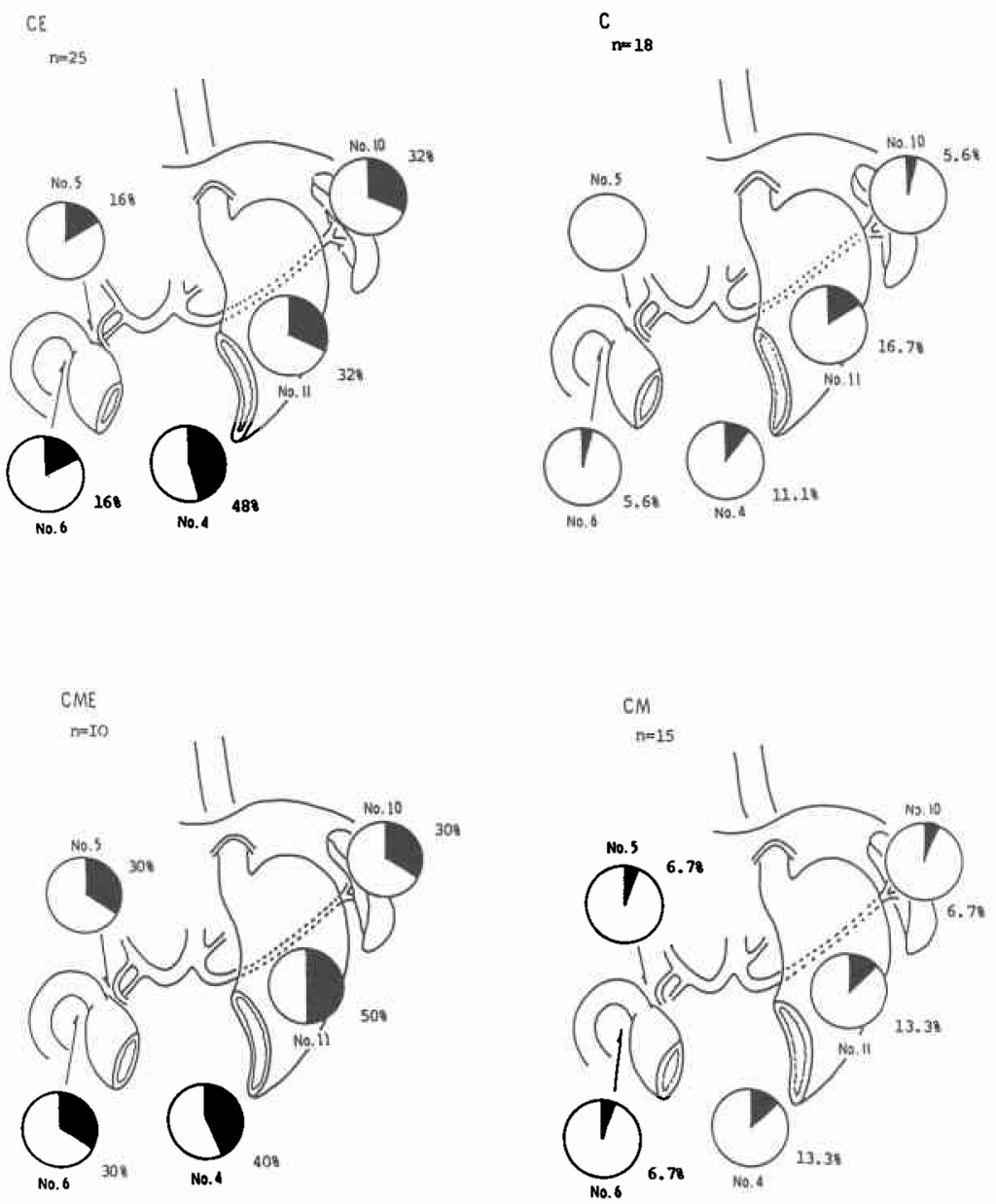
$\mathrm{A}$ 群は pap 9.2\%, tub 1, tub $_{2} 53.1 \%$ で合計 $62.3 \%$ と 分化型が多く特に $\mathrm{EC}, \mathrm{E}=\mathrm{C}, \mathrm{CE}$ では pap $10.9 \%$, $\mathrm{tub}_{1}, \mathrm{tub}_{2} 55.4 \%$ と分化型が多い.

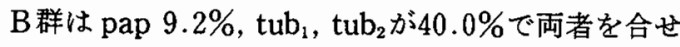
ても $49.2 \%$ と分化型が少なく低分化型が多い（表 4 ）.

7）リンパ節転移率 (stage III)

n因子のみで stage III となった症例は, A 群 6 例 $7.5 \%$, B 群 1 例 $4.2 \%$ にずず，ほとんどが se であっ た. Stage III (術中所見が $S_{2 \sim 3}$ ) の切除に際して, 特 にA群の場合，噴切か全摘か，蓃・脾合併切除の必要 性の有無で問題となる $4 \mathrm{~d}, 5,6,10,11$ 番リンパ節につ いて, 全摘, 膵・脾合併切除が行われた症例の転移率 を検討した。 その結果は CE, CME が類似傾向を示し, No. 10,11ばかりでなく No. 4, 5,6 6も比較的高率に 転移陽性がみられた（図 1).

縦隔リンパ節転移率は, $\mathrm{A}$ 群では $\mathrm{E}=\mathrm{C}(\mathrm{n}=7)$ で No. 108 14.3\%, No. 109 14.3\%, No. $11057.1 \%$, No. $11128.6 \%, \mathrm{C}>\mathrm{E}(\mathrm{n}=35)$ では No. $1085.7 \%$, No. 109 2.9\%, No. 110 11.4\%, No. $1115.7 \%$ B群の CME (n=13) ではNo. $1097.7 \%$, No. 110 15.4\%, No. 111 7.7\%であり, A群の綎隔リンパ節転移率は $23.8 \%$, B 群は $15.4 \%$ ていずれも畽湯長径 $5 \mathrm{~cm}$ 以上, se, sei 症例で, 食道浸潤距離 $2 \mathrm{~cm}$ 以上であった（表 5 ).

8）食道浸潤型式

連続切片が作製され検索された最近の症例につい て, 浸潤型式を 4 型に大別した。 A, B 両群間に若干の 差がみられ，特にB群の低分化型に浸潤型が多い傾向 がみられた（図2）。

9）口側切除断端癌遺残

stage IV は諸条件から口側切除断端癌遺残（以下 ow (十)）すやををえない場合があるため, stage IV を除いた症例についての ow（十）率をみると，A群 $11.3 \%, \mathrm{~B}$ 群 $38.5 \%$ であり特に B 群の ow $(+)$ 例はす

表 5 綖隔リンパ節転移率
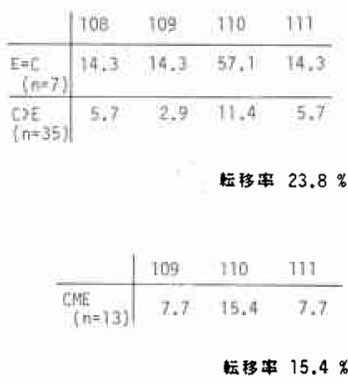

図 2 食道浸潤型式

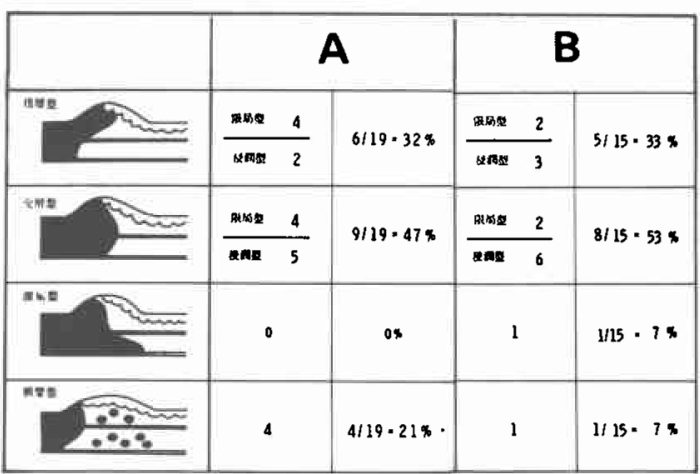

図 3 食道切除断端癌遺残（stage IV 症例を除く）

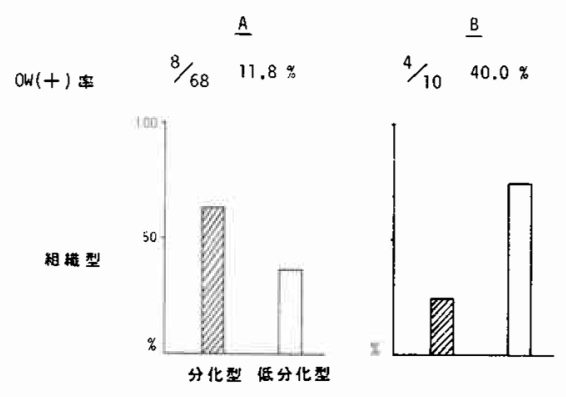

べて stage III であった。 ow（十)例の組織型は，A群 は分化型 $63 \%$, B群は75\%が低分化型であった(図 3). 10）予後

stage 別にみた生存率は, A 群の stage I, II は100\%, $85.7 \%$ の 5 生率で差はなく，IIIは 3 生率 $45.3 \% ， 5$ 生 率22.6\%, IVは 5 生率4.5\%であった. B群の stage I, II は $80 \%, 81.8 \%$ でIIIは 3 生率 $35.0 \% ， 5$ 生率 $30.0 \%$ で, IVは11.8\%であった（図4）.

A 群の stage III の切除術式と予後をみるとアプ ローチによる差はなく, 開腹例では, 全摘十合併切除 群が $45.9 \%$, 噴切十合併切除群が $11.5 \%$ であったが, 両群間に有意差は認めなかった。また，開胸，胸骨糈 切開付加例です全摘十合併切除群が $49.0 \%$, 他の切 除術式群と比較し，有意差はないが良好な成績を得た (図 5 ).

縦隔リンバ節転移陽性例の予後は不良で, stage IV 症例も含め, $\mathrm{A}$ 群は $16.0 \%, \mathrm{~B}$ 群は全例 1 年以内に死 亡した。

\section{考察}

胃上部Cを中心とする胃癌の手術術式には種々の工 夫がなされているがその手術成績は今だ満足すべきる のではない. 
図 4 stage 別にみた予後

\section{$C E, C$}

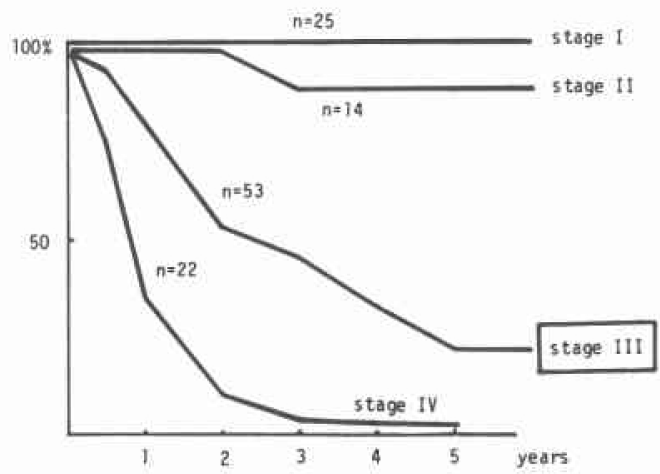

$C M E, C M$

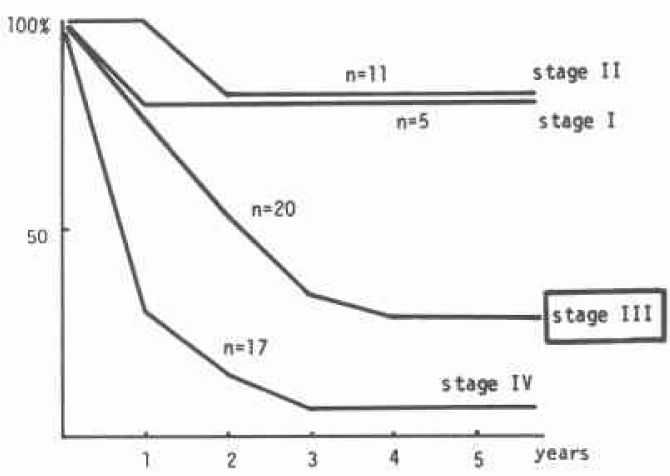

因 5 stage III の切除術式と予後一CE, C-

開腹

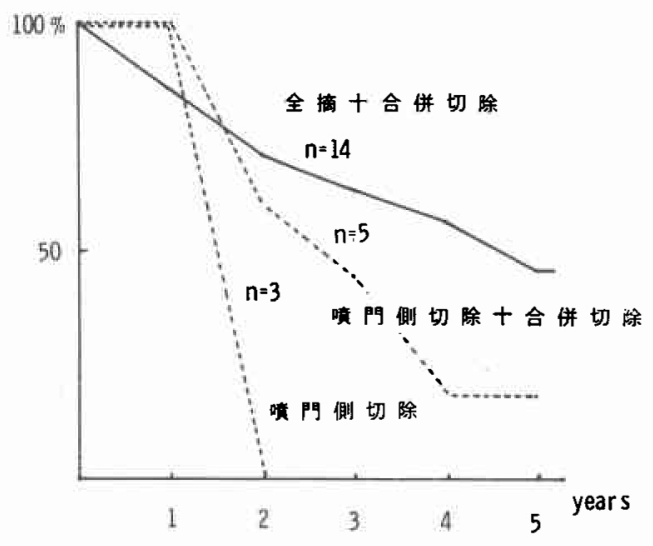

教室でもその時代の背景などにより, 左開胸経横隔 膜アプローチによる下部食道切除と噴切1), 胸骨縦切 開2や非開胸食道抜去法3)などを応用し主たる目的で ある呼吸器などの術後合併症はある程度防止すること は出来たが，その予後より満足すべき結果は挙げえな いため最近は左開胸腹直筋横切開開腹による下部食道 切除と胃全摘手術を中心に行っている4).

噴門部癌も含め上部胃癌を $\mathrm{C}, \mathrm{CE}$ と $\mathrm{CM} \mathrm{CME}$ の 2 群に分けてみると切除率, 組織型, 切除術式などに差 がみられ C, CEと CM, CMEの比較検討を行ってみ た.

予後と stage の関係をみると stage I, II の 5 生率は C， CE 群でそれぞれ $100 \% ， 85.7 \%$ と良好であるが

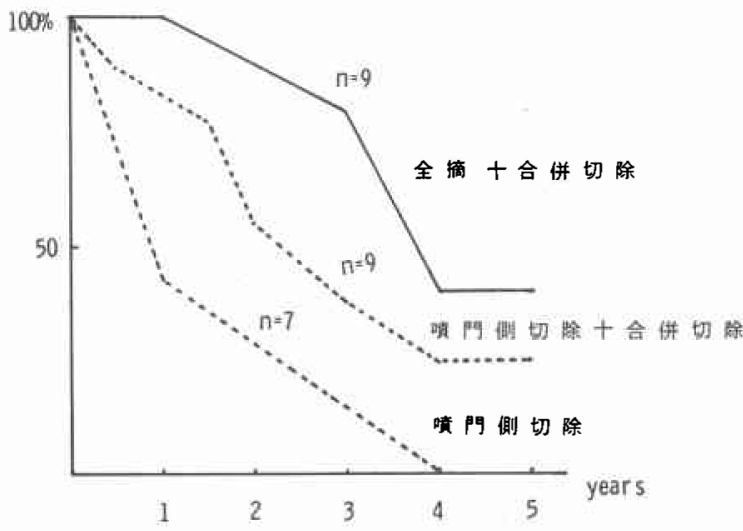

stage III 3 生率 $45.3 \%, 5$ 生率 $22.6 \%$ と不良で stage IV はわずか $4.5 \%$ あった。一方, CM, CME 群 の stage I, II のそれは $80.0 \%, 81.8 \%$ とほ满足すべ きすのであるが stage III は 3 生率 $35.0 \%, 5$ 生率 $30.0 \%$ と不良である。な拉 stage IV は $11.8 \%$ で, 症例 も C, CE 群 $44 \%, \mathrm{CM}, \mathrm{CME}$ 群 $35 \%$ と症例の最も多い stage III に対する手術術式が予後向上のため大切で あり stage III 症例を中心に検討を加えてみた。

stage III, IV 症例が両群とも全体の70\%を占めてい るにもかかわらず姑息的切除も含め $\mathrm{C}, \mathrm{CE}$ 群の切除 率は $98.0 \%$ であが喷門部を中心とするこの部位の癌 腫では通過障害を併うため stage IV でも通過障害を とりのぞくため姑息的切除に終ろうともバイパス手術 
よりは予後が期待出来ると考光て行っているものであ る. $\mathrm{CM}, \mathrm{CME}$ 群の切除率は $55.9 \%$ でるが $\mathrm{P}$ 因子の ほか姑息的にしても切除不能の例や通過障害を伴わな いものも含まれているためである。噴門部癌と上部胃 癌に分けた西ららの報告によれば噴門部癌の stage I, II が40\%であるのに対し上部胃癌では stage I, II が $22 \%$ rtage III 37\%, IV 41\%で特にP因子が多く加 わってくるという。

stage III の切除術式をみると C, CE 群では開胸ま たは胸骨綎切開が $34.0 \%$ に付加され, 切除術式は噴切 27例, 全摘25例, 食道抜去法 8 例などである. $\mathrm{CM}$, $\mathrm{CME}$ 群の開胸または胸骨綐切開付加はわずか $19.3 \%$ で切除術式は全例が全摘である. stage III の切除術式 と予後をみるとアプローチによる差はなく C, CE 群 の開腹単独例では全摘十合併切除の 5 生率が $45.9 \%$, 噴切十合併切除 $11.5 \%$ 之噴切例は予後不良である。 た開胸，胸骨粉切開付加例でも全摘十合併切除の 5 生 率 $49.0 \%$ と噴奵など他の切除術式群に比べて良好な成 樍を得ている。なお前述したごとく $\mathrm{CM}, \mathrm{CME}$ 群は全 例全摘で荤脾合併切除は $90.0 \%$ に行われている。

5 生率を噴切例之全摘例で比較した野口らの成績 でも, 両者とも全体では41\%で差はなく，特に stage I では噴切 $84 \%$, 全摘84\%で stage IV でも噴切 $21 \%$, 全 摘16\%で差はみられないが stage III の 5 生率では噴 切が14\%であるのに対し全摘は31\%で stage III での 噴切の適応は少ない様である。

胃癌の浸潤が食道に及ぶ症例 (CE, CME) の食道浸 潤距離および胸腔内リンパ節転移について高木7は 線所見で食道漫潤が認められなかった宛例で切除標本 で組織学的浸潤例が CE, $\mathrm{CME}$ 全体の $22 \%$ みられた と報告している。非開胸例での食道浸潤距離は肉眼型 で, 食道浸潤距離が $1 \mathrm{~cm}$ 以内では限局型 $13 \%$, 中間型

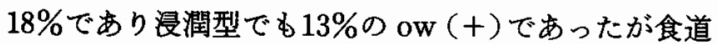
浸潤距離が $2.1 \mathrm{~cm}$ 以上の症例では漫潤型の ow $(+)$ 率 が56\%と高く浸潤型癌で食道浸潤が認められた症例に は積極的に開胸を行って食道の十分な切除が必要であ ると述べている。

私どもの症例で, stage IV は諸条件から ow (十) もやむを得ない場合があるため stage IV を除いての ow $(+)$ 率を開胸例でみると CE では11.8\%であるの に対し CMEでは $40 \%$ が ow (+) であった。 ow (+) 例の組織型は CE は63\%が分化型で CME は75\%が低 分化型であった. CMEの低分化型では食道漫潤距離 が長く右開胸等による十分な食道切除が必要である.
緃隔リンパ節転移率は $\mathrm{CE}$ の開胸例で $23.8 \%, \mathrm{CME}$

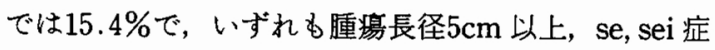
例で食道漫潤距離は $2 \mathrm{~cm}$ 以上であった。しかし食道浸

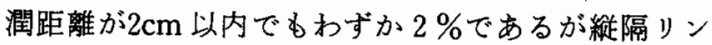
パ節転移がみられたという報告もあり7，更に食道浸 潤距離が $2 \mathrm{~cm}$ 以上では $19 \%, 3 \mathrm{~cm}$ 以上 $26 \%, 4 \mathrm{~cm}$ 以上 では36\%であったという. 特に限局型に比べ中間型, 浸潤型に胸腔内リンパ節転移が高かったと報告してい

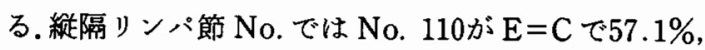
CE 11.4\%, CME 7.7\%であり, No. 111 $\mathrm{E}=\mathrm{C}$ 14.3\%, CE 5.7\%, CME 7.7\%であった.

遠藤ら8タ No. 110 13\%, No. $1118 \%$ No. 108に は検索例での転移はみられなかったと報告しているが 少数例ではあるがNo.108にも転移がみられる事もあ り今後の問題であろう.

次に腹腔内リンパ節転移については全摘か噴切かで 最も問題となるNo. $4,5,6$ について三隅らのは切除例 136例について検討し C , CE ではNo. 5，6には転移は なかったが CM, CMEではNo. 5に16.7\%に転移がみ られたと報告している。野口ら゙は，C，CEでは No. 5 1\%, No. 6 3\%とまれで, この部の転移陽性例 は $\mathrm{n}_{2}$ 以上に著明な転移がみられたという。

一方, CM, CME では No. 4 24\%, No. 6 16\%で C, $\mathrm{CE}$ 群と CM, CME 群では差がみられれるが, stage III に限定した私どもの症例でのリンバ節転移陽性率は CE でNo. 4 48\%, No. 5 16\%, No. 6 16\%であり CME では No. 4 40\%, No. $530 \%$, No. $630 \%$ と高率 に転移を認めて扔り CEでも CMEでも stage III で は噴切の適応は少ないようである。

脾動脈系リンパ節群のリンパ節転移陽性率も CEで No. $1032 \%$, No. 11 32\%であり CMEです No. 10 30\%, No. 11 50\%であり stage III ではリンパ節郭清 から膵脾合併切除の必要があうう。中島ら ${ }^{10}$ も上中部 胃癌に招いてNo. 10, No. 11のリンパ節郭清からみ た膵脾合併切除の適応について術後生存率より検討し $\mathrm{n}_{2}(+), \mathrm{S}_{2}$ 症例では脾温存群の 5 生率は $17.6 \%$ である のに対し䐙脾合併切除群では $21.8 \%$ No. 10, 11に転 移を認めた症例での脾温存群には 5 生例はなく, 荤脾 合併切除群では $27.4 \%$ の 5 生率であると報告している 事からも stage III では朠脾合併切除が不可欠である 5.

鋌隔リンパ節転移陽性例の予後は不良で $\mathrm{C}, \mathrm{CE}$ 群 の 5 生率は $16 \%, \mathrm{CM}, \mathrm{CME}$ 群では全例 1 年以内に死 亡した。 


$$
\text { まとめ }
$$

$\mathrm{C}$ を中とする胃癌を $\mathrm{C}, \mathrm{CE}$ 群および $\mathrm{CM}, \mathrm{CME}$ 群の 2 群に分け切除症例につき検討した。

stage 別にみた生存率は C, CE 群はstage I, II は $100 \%, 85.7 \%$ 5 生率で stage III は22.6\%であった。 CM, CME 群でも stage I, II は80\%, 81.8\%であった が stage III は $30.0 \%$ と両者とも stage III は良い結果 が得られず stage III 症例の手術がこの部の予後の向 上に最も大切なポイントとなる。

stage III 症例の外科的治療成績向上の因子につい ての次の結果を得た。

1） C, CE 群では胃全摘十膵脾合併切除に上る enblockな切除を標準術式とすべきで食道浸潤距離 $2 \mathrm{~cm}$ 以上は開胸による十分な食道の切除と綎隔りンパ節郭 清が必要である。

2) CM, CME 群は C, CE 群に加光てP因子を配慮 したより広範な腹腔内臟器合併切除が必要であろう。 また低分化型の食道浸潤例ではより十分な食道切除が 必要である.

\section{文献}

1）武田良良：左開胸経横隔膜 approach に上る食道 噴門癌の手術。日外会誌 $79: 1237-1239,1978$

2) 莱根康行, 片柳照雄, 伊藤一二: 胸骨縃切開, 経横 隔膜的下部食道到達法. 手術 $30: 785-788,1976$

3）武田化良, 橋本憲三, 岩本元一潘か：食道抜去術自 駼例の検討. 手術 $38: 213-217,1984$

4）掛川暉夫：噴門部癌の手街；左開胸・腹直筋横切 による開腹. 消外 5:1948-1960, 1983

5）西 満正, 加治佐隆, 末永豊邦ほか：食道胃境界領 域癌の特殊性. 手術 $32: 827-833,1978$

6）野口芳一,太田博俊, 高木国夫ほか：胃癌に怙ける 噴門側切除の検討. 日消外会誌 $16: 1470-1476$, 1983

7）高木国夫：食道噴門部癌の手術適応一主としてX 線診断の立場から．消外 $2: 1413-1421,1979$

8）遠藤光夫, 鈴木博孝, 吉田 操注か：噴門部癌一々 くに左開胸横隔膜切開によるアプローチ. 外科治 療 $50: 145-150,1984$

9）三隅厚信, 赤木正信, 馬場霓一郎ほか：噴門癌の外 科的治療に扮ける問題点一近側胃切除々胃全摘衍 の比較一。目消外会誌 $17: 6-14,1984$

10）中島聰總，山瀬博史，太田博俊注か：上中部胃癌の リンバ節郭清からみた胘脾合併切除の適応。日消 外会誌 $16 ： 1650-1655,1983$ 